\title{
Norois
}

Environnement, aménagement, société

$241 \mid 2016$

Innovation sociale et développement des territoires dans les campagnes européennes

\section{From technological to social innovation: objectives, actors, and projects of the European rural development program (2007-2013) in the Puglia region}

De l'innovation technologique au développement social : objectifs, acteurs et projets du programme européen de développement rural (2007-2013) dans la région des Pouilles

\section{Marilena Labianca}

\section{OpenEdition}

\section{Journals}

Electronic version

URL: https://journals.openedition.org/norois/5999

DOI: $10.4000 /$ norois.5999

ISBN: 978-2-7535-5504-4

ISSN: $1760-8546$

\section{Publisher}

Presses universitaires de Rennes

\section{Printed version}

Date of publication: 30 December 2016

Number of pages: $49-65$

ISBN: 978-2-7535-5483-2

ISSN: 0029-182X

\section{Electronic reference}

Marilena Labianca, "From technological to social innovation: objectives, actors, and projects of the European rural development program (2007-2013) in the Puglia region", Norois [Online], 241 | 2016, Online since 31 December 2018, connection on 14 January 2022. URL: http:// journals.openedition.org/norois/5999; DOI: https://doi.org/10.4000/norois.5999 


Presses
Universitaires
de Rennes

\title{
From Technological to Social Innovation: Objectives, Actors and Projects of the European Rural Development Program (2007-2013) in the Puglia Region
}

\author{
De l'innovation technologique au développement social : \\ objectifs, acteurs et projets du programme européen de développement rural (2007-2013) \\ dans la région des Pouilles
}

\author{
Marilena LABIANCA
}

Tel.: +39 3402998265 - Università del Salento, Dipartimento di Scienze dell’Economia, Via Monteroni, 73100 Lecce, Italy. (labiancamarilena@libero.it)

\begin{abstract}
In Europe, innovation is widely considered a key factor in a region's economic growth and competitiveness, although its social and cultural dimensions are often overlooked. In this sense, the LEADER approach represents an emblematic change. The interpretation of innovation is significant with regard to the strategies and governance models implemented, especially on a local scale. As such, the role of innovation and knowledge in the development of territories is important in regions of the Convergence Objective, and particularly in rural areas. In Puglia, the rural development strategy allocates a higher amount of financial resources on axes 3 and 4 of the rural pillar of the common agricultural policy; therefore, it gives great importance to governance. Incorporating a literature review, this article aims to understand the interpretation of innovation and its declination at the local level through the analysis of main regional programming documents for the period spanning 2007-2013. It focuses on initiatives and projects led by local action groups (LAGs) of the LEADER program.

Résumé : En Europe, l'innovation est largement considérée comme l'un des facteurs-clés de la croissance économique et de la compétitivité régionale, bien que ses dimensions sociales et culturelles soient souvent négligées. En ce sens, l'approche LEADER représente un changement emblématique. L'interprétation de l'innovation est significative des stratégies et des modèles de gouvernance mis en œeuvre, spécialement à l'échelle locale. À ce titre, le rôle de l'innovation et de la connaissance dans le développement des territoires est important dans les régions de l'Objectif de Convergence et en particulier dans les régions rurales. Dans les Pouilles, la stratégie de développement rural concentre une plus grande proportion des ressources financières sur l'axe 3 et 4 du pilier rural de la politique agricole commune et accorde de ce fait une grande importance à la gouvernance. A partir d'une revue de la littérature, l'article vise à comprendre l'interprétation de l'innovation et sa déclinaison à l'échelle locale à travers une analyse des principaux documents d'aménagement régional établis pour la période de programmation 2007-2013. Il se concentre sur les initiatives et les projets portés par les groupes d'actions locales (GAL) du programme LEADER.
\end{abstract}

Keywords: innovation - LEADER - governance - actors - territorial projects - Puglia

Mots clé : innovation - LEADER - gouvernance - acteurs - projets territoriaux - Pouilles 


\section{INTRODUCTION}

In the geography and planning literature, innovation is considered an important factor that influences regional performance and growth, even if its social and cultural dimensions are often overlooked. In recent years, innovation has been conceived in the literature as a co-evolutionary learning process that occurs within social networks. In this sense, the LEADER approach represents an emblematic shift that focuses on building the economic, social, cultural, and institutional capacities of territories and serves as a basis for sustainable rural development (Dargan and Shucksmith, 2008 ; Shucksmith, 2000).

In Europe and Italy, knowledge and innovation represent fields of interventions that overlap with development programs that span the period from 2007-2013. At the community level, the Union has several instruments for a broad-based European Union (EU) innovation policy, particularly comprised of the Cohesion policy instruments ${ }^{1}$, the Research Framework Programme (2007-2013), and the Competitiveness and Innovation Framework Programme (2007-2013). The Structural Funds increasingly emphasize the role of research and innovation as crucial factors for regional development. The importance of innovation is also highlighted in Community strategic guidelines for rural development for 2007-2013 (European Union, 2009). For this reason, both the National Strategic Plan for Rural Development (NSP) and the Regional Rural Development Programs (RDP) tend to recognize the strategic role of innovation when compared to the previous program. However, it is important to point out that innovation processes cannot be reduced to matters of business and production processes alone, at least from a technological and economic sense, but they should be understood in a systemic way. Innovation processes are the result of a complex process of social innovations in which the role played by specific actors is crucial, especially in certain rural contexts (Dargan and Shucksmith, 2008; Ward and Brown, 2009; Copus and de Lima, 2015).

The innovation to which this contribution refers is thus not expressed solely from economic, productive, and technological perspectives, but it is also the

1. About Cohesion Policy, see Prezioso 2007; 2008. result of changes in governance and adjustments, where the role of the actors, as well as their ability to organize and to coordinate at different scales is important, and this should be facilitated by the presence of local institutions that absolve tasks of animation and coordination in the territory. In this way, innovation is considered as a dynamic, open, and interactive process that focuses on learning and networking. This is particularly true for the agricultural sector - a sector which, in recent years, has been characterized by a deep change in the models of governance and government that have been adopted. Specifically, what characterize the most recent developments in agricultural policy are "the inclusiveness of decision-making" and their "verticalization"; this determines the shift from structures of government to governance processes (Società Geografica Italiana, 2012, p. 32-33). Then, regarded as social and territorial constructs, the innovation process is particularly sensitive to the effects of geographic contexts that differentiate between the diverse forms of coordination and networking of the actors involved in economic development and territorial management (Fontan et al., 2004).

Considering both European and national rural development policies, the role of innovation and knowledge in the development of territories assumes particular importance, especially for the southern regions of Italy that are included in the Convergence Objective (as defined in the programming cycle 2007-2013) (see figure 1). Puglia is among these regions that are defined by their lagging development; it also falls into this category in the new programming cycle spanning 2014-2020. For the 2007-2013 programming cycle, and based on the community and national strategic guidelines, the region has developed the Rural Development Programme (RDP), an implementation instrument of the rural development strategy, which allocates a higher amount of financial resources on axes 3 and 4 of the rural pillar of the common agricultural policy than the limit set by the EU. In fact, most Italian regions chose to level the sum of the total expenditure at around $15 \%$, corresponding to a minimum expenditure European Agriculture Fund for Rural Development (EAFRD) provided by the EU. In this sense, this can be considered a clear indication that regions do not point on rural development, in the wider sense of local development, but only on 
agriculture (Sotte and Ripanti, 2008). As shown by Camaioni and Sotte (2009, p. 34), these axes are deeply connected and revolve around three main features: the territorial dimension, integration with other programming instruments, and the relevance of governance.

The characteristics of regional programming revolve around planning that is based on a coordinated, integrated, and participatory approach between local actors; it also acknowledges the role of innovation. This paper, stemming from the literature, aims to understand the interpretation of innovation, its declination, and the role of Local Action Groups (LAGs) in the Puglia region. In the first section of the paper, the literature provides some important keys to better understand this case study. In the second part, the situation in Puglia is presented. Here, the aim is to understand the interpretation of innovation, its declination, and the role of LAGs through an analysis of the main regional programming documents for the 2007-2013 cycle, specifically the RDP of the Puglia region, the Local Development Plans (the contents of which, according to the LEADER approach, make explicit reference to integration and innovation), as well as the initiatives and projects of the LAGs operating in the region. Based on the obtained results, in the last section of the paper, the interpretation of innovation, as well as its link with the strategies implemented and the governance model adopted (especially at the local scale), will be discussed.

\section{INNOVATION, NETWORKS, AND EUROPEAN POLICIES FOR RURAL DEVELOPMENT}

The current rural development policy of the EU is based on a history of programming, which recognizes the role and the basic advantages that both innovation and creativity offer for citizens of rural areas, as well as for all users of the European countryside (EC, 2009; 2013).

The Community Strategic Guidelines for Rural Development has been promoting innovative approaches since the early 1990s. The fact that innovation is still a priority in the next programming cycle (2014-2020) serves as a testament to the importance of these political priorities.
In 2009, the year of creativity and innovation in Europe, both innovation and creative thinking were considered important for the promotion of sustainable development systems, particularly for those involved in rural development and the politicians involved in seeking answers to fundamental questions, such as competitiveness, quality of life, diversification, and territorial cohesion (EC, 2009).

The diversity of Europe's rural contexts, as well as the new opportunities and challenges faced in terms of climate, society, and infrastructure, introduced the role of innovation to the rural sector. For these reasons, different tools have been provided and developed to support innovation, particularly in marginal and rural areas (Commission of the European Communities, 2010; EC, 2014a; 2014b). Furthermore, a significant number of strengths, weaknesses, opportunities, and threats across the European territory in relation to research and innovation, as well as the capacity of regions to meet established goals, have been identified. The analysis of specific national contexts shows distinctly different potentialities and policies in operation (Espon Siesta, 2012; Espon Edora, 2012 ; Espon KIT, 2012). In particular, both the complexity of and the different ways in which innovation is expressed explains the failure of a "one-size-fits-all" policy to innovation, as is the case for generic research and development (R\&D) incentives. Conversely, innovation modes specific to each area must be addressed, as based on local specifications and capabilities to accumulate knowledge and subsequently turn it into innovation and growth (Espon KIT, 2012). The geographical framework of a knowledge economy highlights that there is a significantly impressive, yet unexpected, gap in its spatial distribution. There are different types of innovation (product, process, management, and social innovation). The discrepancy between knowledge and spatial innovation can only be understood by identifying the different paths to innovation and modernization that every region in Europe follows, as based on local conditions. This can ensure the creation of knowledge and the ability to exploit knowledge for innovation. The case studies of the KIT project provide an inductive proof "that the territorial elements conceptually identified as crucial in shaping the territorial patterns of innovation are indeed fundamental for the way in which regions innovate" (p. 49). 
Therefore, each area faces challenges associated with both local and global contexts. In this sense, innovation is something more complex. As of the late 1990s, the report - produced by the Innovation working group of the LEADER European Observatory (1997) - tried to highlight the nature of the concept of innovation, as applied to rural areas; it also stated that innovation appears to be an initiative of the local actors who bring new solutions to the specific challenges of a given area. For these reasons, understanding the nature of innovation in rural areas requires a careful and systematic practice of the local actors themselves.

With regard to agriculture, innovation expresses itself in very different forms than other productive sectors. However, due to its structural and economic conditions, the agricultural sector has a low propensity for innovation. This has resulted in a strong public support in research. In recent years, the increasing complexity of the sector required a rethinking of policies to support innovation. The linear model of technology transfer has been replaced by an interactive model of network systems that are able to integrate knowledge, production, adaptation, advice, and training (Società Geografica Italiana, 2012).

In recent years, the analysis of the milieu as part of the innovation process has been the subject of numerous studies, and this is mainly due to the global and structural changes in the economy. Important contributions to the discussion about the importance of social dynamics and the role of the local context in the formation of the innovation process stem from several studies, including those of the European Group of Research on Innovative Environments (GREMI) (1986), Aydalot (1985; 1986) and Boschma (2005). They show the importance of the local context in the formation of the innovation process. The local community is in fact considered an "incubator of innovation". In particular, regarding the relationship between technological innovation and milieu, the focus is on local knowledge and thus on the collective behavior sedimented in the course of history in a given territory. According to Aydalot $(1985 ; 1986)$, innovation certainly depends on the variables defined at local or regional levels. At the base, there are the territories, their organization, and their ability to elaborate on a common project, all of which serve as the foun- dation for innovation; these elements consequently determine those areas that are more or less innovative. Regarding the innovative milieu approach, Crevoisier (2004) argues that it can be considered an ideal method, as it brings together three fundamental paradigms: the technological paradigm that is based on the recognition of innovation; knowledge and know-how, which provide competitive advantages; and the organizational paradigm that focuses on the role of networks, cooperation, the relational capital, and the territorial capital that considers the role of proximity.

A critical stand on the role that proximity plays in innovation has been proposed by Boschma (2005). He certainly supports the importance of geographical proximity on interactive learning and innovation; however, he notes that it cannot be considered in isolation from the other dimensions of proximity, nor can it even be considered a necessary or sufficient condition so that learning can take place. Another important aspect is that all dimensions of proximity (cognitive, organizational, social, institutional and geographical proximity) have their own limitations; in fact, too much or too little proximity may be detrimental to interactive learning and innovation. In addition, a certain combination of specific mechanisms can offer solutions to problems associated with coordination and lock-in, encouraging both coordination and control in cases of too little proximity, as well as openness and flexibility in cases of too much proximity. Another important aspect is that when assessing proximity, it is essential to adopt a dynamic approach, while also understanding how each dimension of proximity can change and evolve over time.

With respect to the different approaches to innovation in the literature (the milieu innovateur, the regional innovation system, the industrial districts, the learning regions, and the regional clusters), Shearmur (2011) argues that these approaches have been proposed to explain the different dynamics of regional economies, highlighting - as appropriate the different mechanisms or conditions that explain the growth or innovation in certain regions. Thus, depending on the approaches, different dimensions are highlighted, such as the local culture, traditions, and trust, which involve the exchange of knowledge and collaboration between companies, the role of local institutions and culture, codified and tacit 
knowledge, and the presence of regional clusters. In this way, these concepts can be viewed as a particular example of a mechanism that can be enabled or facilitated by the regional context.

Therefore, according to the author, it may also be true that different mechanisms operate in different territories; thus, it can be said that the processes of regional development vary not only in time, but also in space. As shown by van Hemert et al. (2011), another significant aspect is that with all of the approaches discussed above, the increasing importance of a network approach and its closely related elements, such as territorial embeddedness, interactive learning and absorptive capacity, and institutional thickness, are stressed. In particular, as Murdoch (2000) argues, in recent debates about exogenous and endogenous development, networks may also have particular utility when understanding various forms of rural development. Specifically, the conditions of the global economy (such as rapid technological change) are, in some way, reflective of the importance of innovation and learning; this is thought to be conducted more quickly within associations of many small firms that are deeply embedded in local societies and cultures. Thus, for this reason, the literature has sought examples of districts and innovative clusters. However, proponents of this paradigm often neglect the existence of different types of networks in other territorial areas.

More recently, the most successful rural economies have emerged in those areas that hold a rich and diverse array of economic and social forms. This has led to the rethinking of rural development strategies and has sparked interest in the networks. More attention is thus placed on associations and economic networks, and the ways in which they facilitate learning and innovation. However, the paradigm of the network should not be used to suggest that there is a single model of development. Rather, it is fundamental that one recognizes the different types of networks that interact in different ways and with a different number of pre-existing conditions; this implies that the strategies adopted by development agencies will have to be tailored to the needs of different rural areas. In this sense, the network approach discussed by Murdoch (2000, p. 417) "allows us to hold inside and outside together within one frame of reference", and that each frame of reference must be matched to the particu- lar rural context; it is also important to emphasize "that it is not the networks themselves that are so important but the objects and relations that flow through them".

Similarly, Fløysand and Jakobsen (2010) proposed an analytical framework pertaining to innovation that is based on the concept of the social field. However, the authors argue that recent contributions about the system of innovation are characterized by instrumentalism, which considers innovation to be a predictable and standardized process. The authors also propose a relational turn within innovation studies; this approach should be adopted to encourage one to reflect on the ideologies and networks that underlie innovation studies and innovation policy. They emphasize the fact that there is a significant difference between the network concept and the concept of social fields; in fact, "the latter pays attention to the time-spatial scale of social relations emphasizing their historical and geographical scope. This brings it more into line with the relational turn within economic geography, which stresses the importance of space-time contexts in constraining and enabling economic innovation, as well as other related concepts paying specific attention to time-spatial aspects" (Fløysand and Jakobsen, 2010, p. 332). This allows for a stronger focus on the structure-agency dynamics that constitute innovation. It also allows for a stronger confrontation of the complexity of managerial and organizational practices. The scale of a social field can thus be defined by referring to the number of actors, their relations within a particular social field, and the distribution of these relations in both time and space. Therefore, to construct social fields, the repercussive interaction of a certain historic duration is important; this approach is systemic - in fact, all actors simultaneously take part in these various fields on different scales. This fact also "implies that innovation practices are multifield based, but normally with some sort of field hegemony" (Fløysand and Jakobsen, 2010, p. 329). The novelty of this approach is the capacity to integrate the informal knowledge, rules of conduct (cultural aspects), multiple types of relational practice (social aspects), and geographical scale (territorial aspects) of a specific innovation practice into one analytical framework. In this way, innovation is considered a dynamic, open, and interactive process that focuses on learning and 
networking, and it is not used instrumentally as a standardized model to adjust system failures.

When considering European policy, starting from the 1990s, the EU developed a policy framework for innovation that was based on a systems approach, under which innovation was not intended to be regarded as a linear and unidirectional flow of knowledge from research to practice; rather, it was to be viewed as a process that was highly based on the learning that takes place within complex and diverse relational networks (Knickel et al., 2009). From this perspective, the EU has strongly favored the establishment of public-private partnerships, transnational networks, policies, and project enterprising. This resulted in a commitment to build more effective relationships between innovation agencies, private companies, research organizations, and public institutions. For various reasons (such as the presence of institutional barriers and the difficulty of introducing research), agriculture is one of the areas in which this approach to systems innovation has been applied. The supportive frameworks that predominated before the reforms of the Common Agricultural Policy (CAP) were developed over the past 15 years had encouraged a model of innovation systems based mainly on the efficient production of primary agricultural products and trade; all of this has been driven primarily by economic considerations and a particular image of a modern agricultural sector (Knickel et al., 2009) ${ }^{2}$. In particular, in the 2007-2013 programming cycle, a reorientation of CAP has been underway; this reflects both the situation and trends of rural areas, as well as the strategic guidelines set out by the European Councils, emphasizing the economic, environmental, social, and sustainability factors in rural areas, with rural communities serving as the starting point for these policies. However, much of the national studies that deal with national innovation systems show a tendency to prefer technological innovations, with results evident in national policies (Knickel et al., 2009). Research and policy deal with innovation, as based on its most common understanding - especially pertaining to technical and economic innovation. The focus is thus on materials and product innovation, methods, or

2. Evidence from a European study of Rural Development Regulation Programmes focuses on the performance of this experiment in its initial years, showing the need for institutional adaptation (Dwyer et al., 2007). production processes, as well as on marketing and organizational innovation in the field of economics. Considering that innovations with a clear intent are well studied and defined, the understanding of socalled social innovations have not been analyzed in detail (Neumeier, 2012); as such, the policies that have been explored are mostly centered on urban regions, and they are science- and technology-oriented (Proost et al., 2009). As a result, in public discussions and in policy, innovation is still almost exclusively treated and perceived as economic, which focuses on technical efficiency, as well as on the commercialization of science and technology (Neumeier, 2012). In this sense, it can be said that this definition of innovation is based on orthodox economic thinking, which merely considers knowledge in its current form - as produced, codified theory, standards, and patents; in this way, knowledge is interpreted in terms of stock, or as a certain set of information and technologies available on the market at a given moment in time. As such, a standardized concept of innovation focuses on process and product, while in terms of governance, it can be said that this conception corresponds to a particularly hierarchical, prescriptive, and top-down model (Conti, 2013; Jessop, 1995) .

\section{LEADER APPROACH, SOCIAL CAPITAL AND INNOVATION}

There is important literature dealing with the role of innovation in rural development (Dargan and Shucksmith, 2008 ; Neumeier, 2012; Ward and Brown, 2009 ; Murdoch, 2000; Dwyer et al., 2007). Innovation is a key concept of the LEADER Community Initiative (Leader European Observatory, 1997). LEADER stands for "Liaison entre actions de développement de l'économie rurale”. As its name suggests, this method aims to mobilize and deliver rural development in local rural communities, rather than adopting a fixed set of measures to be implemented. It can play an important role in encouraging innovative responses to old and new rural problems. In fact, it can be considered a sort of "laboratory" for building local

\footnotetext{
3. With respect to Fordism and post-Fordism, Jessop (1995) argues that this involves a shift from a top-down hierarchical political organization to placing emphasis on promoting and/or steering the self-organization of interorganizational constructs, which feature new mechanisms of organizational coordination and programming.
} 
capabilities and for testing out new ways of meeting the needs of rural communities (EC, 2006). Since it was launched in 1991, the LEADER initiative has been working to provide rural communities in the EU with a method to involve local partners in steering the future development of their area. The seven key features of the approach are: area-based local development strategies; the bottom-up elaboration and implementation of strategies; local public-private partnerships; LAGs; integrated and multi-sectoral actions; networking; and cooperation and innovation (which are to be understood in a broad sense) (EC, 2006). All of this means that an integrated, multi-sectoral, bottom-up development plan, as well as participation of the local community at all stages, capacity building, cooperation, the development of social capital, and the valorization of identities are adopted. Therefore, it can be said that this approach is actually innovative and focuses on building and developing social capital.

As Lee et al. (2005) argue, the notions of social capital and identity have become powerful metaphors in the development policies in contemporary rural areas and beyond. These concepts, however, are derived from concrete social relations and are thus constructed through processes in which memberships include traded networks and where communities are built. The promotion of networks and social capital are examples of interventions in the development process that can have long-term and positive results. At the same time, however, networks and social capital can be used by individuals or groups to limit the acquisition of benefits arising from the change. This means that supporting the development of rural communities must be understood as an approach that should be worked with to strengthen the capacity of individuals and groups within their communities. This approach aims to strengthen communities by increasing their confidence, knowledge, and people skills, as well as their ability to work together. In the EU, this approach has been tested under the Community Initiative LEADER. In this sense, the networks are positive when they facilitate collective learning, allowing one to share in the success and generation of a wider social acceptance. The share capital cannot be thought of as the property of closed, bounded rural communities, which merely perpetuates the myths of rurality as a reserve of old traditions.
Conversely, this approach is very much linked to the ideas of place and identity. For the authors, if share capital yields positive benefits, it is likely to be associated with a plurality of cultural identities, a plethora of different social networks, a mixing and interlacing of spatial scales, and strong links to the multiple historical themes that characterize rural areas in Europe.

More specifically, on the issue of rural development and the role of individuals and innovation, Neumeir (2012) discusses social innovations. This is an ambiguous concept for Cloutier (2003), as it can be considered as a new response to a negative social situation - a situation that is likely to occur in all sectors of society ${ }^{4}$. In this way, social innovation aims to develop the individual, the living space (territory), or the company. As such, it does not assume a particular form. Sometimes it is procedural; sometimes it is organizational or institutional. Social innovation thus results from the collaboration of a variety of actors. From this perspective, social innovation can be regarded as a process of collective learning and knowledge creation which, for some theorists, requires the participation of users and, to varying degrees, the creation and realization of social innovation. With respect to rural development, Neumeier (2012) argues that social innovations play an important role in rural development, but they have not yet been well researched. It is an interesting concept that should be taken seriously and better elaborated upon; it differs substantially from the traditional concept of innovation, especially economic forms. As such, rural development builds upon neo-endogenous strategies that can be successful, but only if they also encourage and support the development of social innovations. Following an analysis of the literature, the author came to the conclusion "that social innovations can be generally understood as a change in the attitudes, behaviour or perceptions of a group of people joined in a network of aligned interests that, in relation to the group's horizon of experiences, leads to new and

\footnotetext{
4. Social innovation is primarily anchored to the process of the participation of beneficiaries and stakeholders, as well as to the quality of partnerships. In this regard, the Le comité de pilotage du Forum sur les innovations sociales has identified five criteria for social innovation: innovative; experimental nature in a specific context; state of spirit and risk-taking by the actors involved in the project; impact on social policies at the national or local level; quality of partnership among both usual and players; and the participation of the beneficiaries, volunteers, and residents of the area affected by the project (Cloutier, 2003, p. 5).
} 
improved ways of collaborative action in the group and beyond" (Neumeier, 2012, p. 65). This essentialist understanding leads the author to state that social innovations play an important role in integrated rural development, although open issues remain to be resolved. The mobilization of neo-endogenous development strategies characterized by valorizing and exploiting local resources - physical and human - emphasizes more democratic and participative forms of local government, focusing on the role of social capital (Ray, 2006); it is also attracting more and more interest, and it is a key driver of the LEADER approach (EC, 2006). However, the success of these strategies depends heavily on the ability to mobilize public participation, which enhances not only traditions, but focuses on social renewal, as well as on economic and cultural factors. Paradoxically, however, although social innovation seems to be one of the keys to successful rural development, its role in the area is often overlooked. Social innovation is not well supported by local, regional, and national financing (Neumeier, 2012).

\section{INNOVATION IN RURAL PLANNING FOR THE 2007-20I3 PROGRAMMING CYCLE: the situation in Puglia}

In Europe and Italy, knowledge and innovation are domains of intervention that are found transversally in the 2007-2013 development plans. In fact, both the NSP and the RDP recognize the strategic role of innovation to a greater extent than in the previous programming cycle (De Rubertis et al., 2015; INEA and CRA, 2009). Thus, it can be argued that the role of innovation and knowledge in the development of territories (mainly rural) is particularly important in regions under the Convergence Objective $^{5}$ (figure 1), and specifically in Puglia, based on the 2007-2013 planning cycle.

The region covers about $6.4 \%$ of the national territory. One of the indicators used to define the importance of rural areas (a common indicator of

5. A substantial difference characterizes the regions in relation to the key objectives ("convergence" or "competitiveness and employment") of the European regional policy. The "Convergence" Objective aims to promote conditions for growth and employment, leading to real convergence between the member states and the less developed regions. In Europe, this objective concerns 17 member states and 84 regions, and it affects a total population of 154 million, whose per capita gross domestic product (GDP) is less than $75 \%$ of the community average (Ministero dello Sviluppo Economico, 2007). context number 2) is based on the OECD's (2006) definition, which considers the percentage of the population living in rural municipalities (i.e., with less than 150 inhabitants per square $\mathrm{km}$ ) in a NUTS III region. According to this definition, rural areas represent about $49.7 \%$ of the region, while in Italy, this value is about $77 \%$; it is $92 \%$ in the EU. Approximately $17 \%$ of members of the population live in the rural areas of Puglia, while 14.4\% reside in significantly rural regions. These areas produce about $30 \%$ in gross value add (compared to $44.5 \%$ in Italy and $45 \%$ in the EU) and they provide $29.6 \%$ of employment (compared to $46.4 \%$ in Italy and $51 \%$ in the EU), although as in the rest of Europe, these areas are characterized by delays with respect to "non-rural" socio-economic areas (Regione Puglia, 2008).

However, the OECD methodology, as highlighted in the NSP, "does not allow to adequately capture the differences within the provinces, generally relevant within the Italian territory". Therefore, in the analysis of the socio-economic context of Puglia, the RDP always generally refers to the methodology and the classification of the territory in macro homogeneous areas developed by the NSP, which divides the region into four main homogeneous areas: urban poles; rural areas with specialized intensive agriculture; intermediate rural areas; and rural areas with development problems. Based on this classification, rural areas in Puglia cover about 93\% of the region and have a population of approximately $79 \%$ of the regional total (Regione Puglia, 2008, p. 4734-4735).

For the 2007-2013 planning cycle, and based on community and national strategic guidelines, the region drafted the RDP - an instrument of implementation of the rural development strategy - which preferred to allocate a higher percentage of financial resources on axes 3 and 4 than to the other Italian regions (figures 2 and 3). The region, whose territory is almost entirely covered by the presence of LAGs, is also among the regions under the Convergence Objective that have placed the greatest amount of faith in the LEADER approach (as shown in figures 2 and 3). These regions have anticipated that the axis 3 measures would be accomplished through the LAGs, to which quite high average funding was allocated. This shows a specific strategic orientation on the part of the region. Specifically, the axes in question (3 and 4) are deeply connected and revolve 


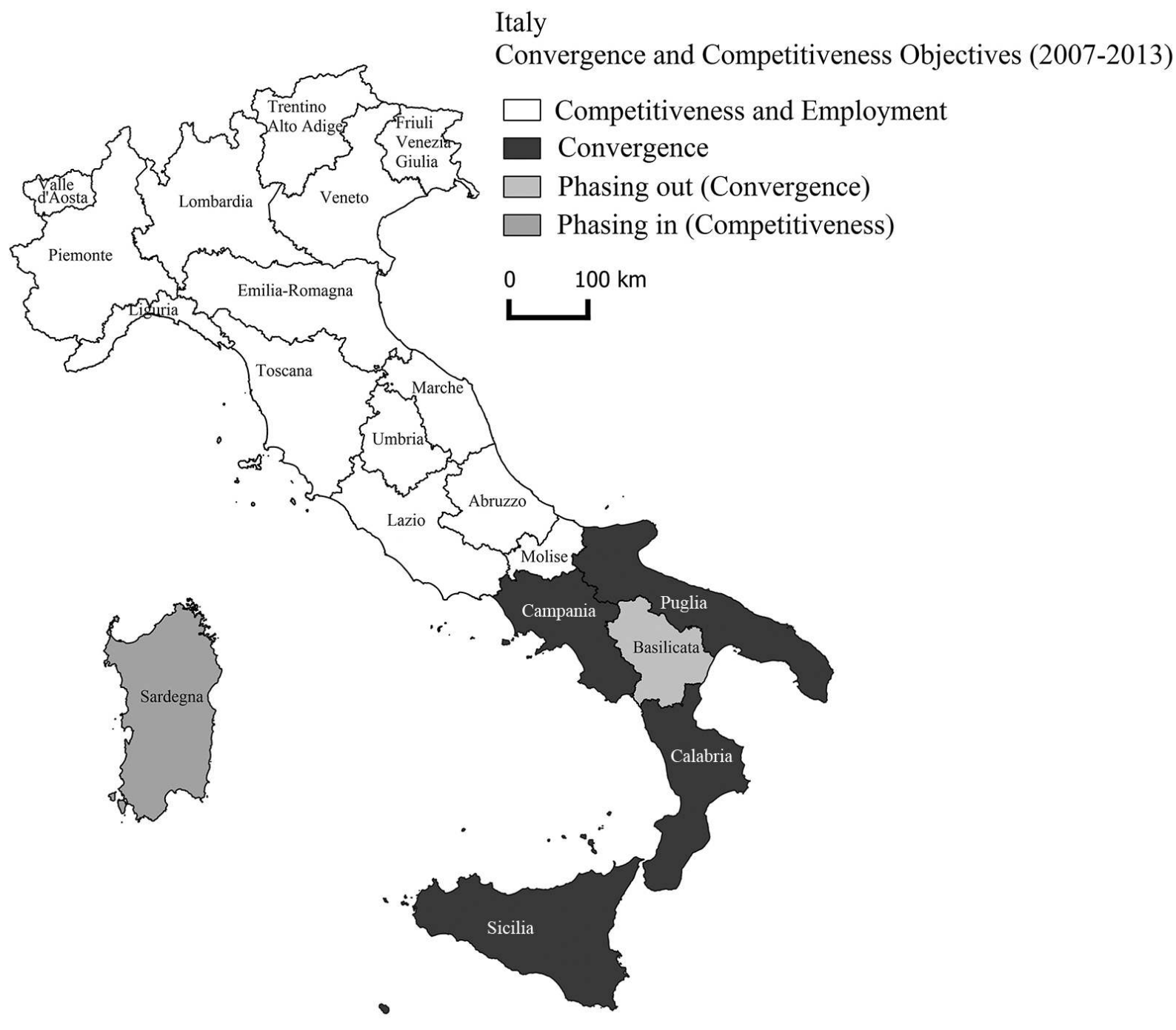

Figure 1: Classification of the Italian regions from the cohesion policy of the European Union (2007-2013) (Source: Our elaboration on Ministero dello Sviluppo Economico, 2007, p. 6)

Classement des régions italiennes d'après la politique de cohésion de l'Union européenne (2007-2013)

around three main features: the size of the territory; integration with other planning instruments that exist in the local area; and the importance of governance. As Camaioni and Sotte (2009, p. 34) argue, when continuing to think in terms of policies, it can be said that axes 3 and 4 greatly benefit from the diversification of agricultural activities, quality of life, and the LEADER approach. Moreover, the features that mark regional programming concern planning that is based on a coordinated, integrated, and participatory approach involving the actors from the territory; this approach also recognizes the role of innovation (Regione Puglia, 2008).
A preliminary reading and textual analysis of the RDP for the region not only highlights the role played by innovation in rural development, but it also brings attention to a strong ideological dimension (see also De Rubertis et al., 2015). During the selection of the LEADER areas, the region emphasizes that in addition to respecting certain characteristics (such as the homogeneity and contiguity of the territories, the adoption of a bottom-up approach, integrated development, and the implementation of specific methods partnership involvement), the initiative would give higher priority to those areas that are able to adopt innovative strategies for the local context (Regione Puglia, 2008). 
Figure 2: Distribution of resources on the axes 3 and 4 in the Italian regions (Source: Our elaboration on Sotte and Ripanti, 2008, p. 15 and Regione Puglia, 2008)

Répartition des ressources sur les axes 3 et 4 dans les régions italiennes

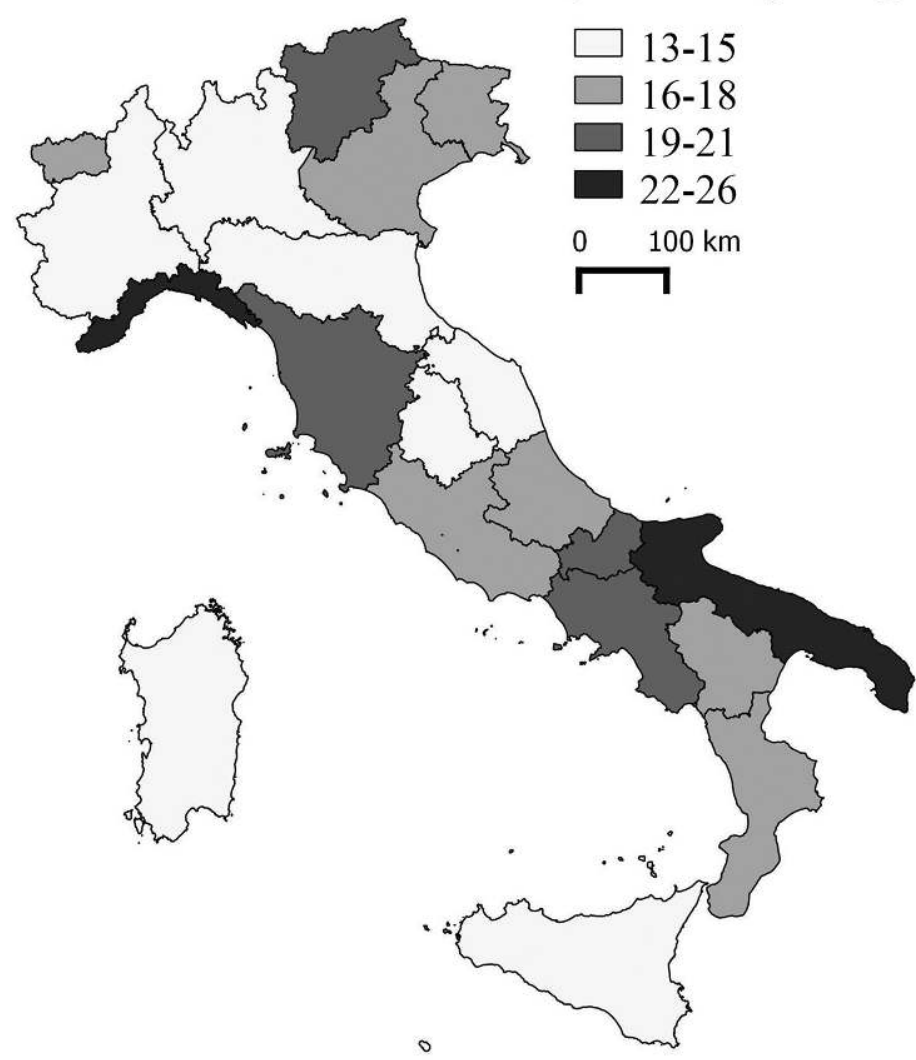

Financial resources for Axis 3 and 4 ( $\%$ of total spending in the region)

Considering these aspects, the aim is to understand how the Puglia region and the territories constituting the LEADER areas have interpreted innovation from both a programmatic and operational point of view. For this purpose, the research was divided into two interconnected phases: 1) through a textual analysis of the key documents for rural planning in the region (specifically, the RDP of the Puglia region and the Local Development Plans of the 25 Apulian LAGs), one must come to an understanding of the interpretation given to the term "innovation"; and 2) through the census and analysis of public calls from 2010-2015, it is important to evaluate the role of LAGs, as well as the objectives of the projects promoted by them ${ }^{6}$.

Firstly, a textual analysis of the RDP reveals that in addition to a significant increase in the frequency

6. The public calls aimed at selecting the most meritorious initiatives and projects are the means through which most of the expenditures detailed in the plans are financed. The census was carried out by collecting the calls, which was achieved by accessing the official website of Rete Rurale Nazionale (the census was carried out until June 2014). of use of the term "innovation", its particular meaning heavily depends upon European and national guidelines (as clearly indicated in the scheme of the Plan) ${ }^{7}$. In the section titled, "Investment in human and physical capital" (according to the Community Strategic Guidelines), axis 1 is reduced to "Upgrading of infrastructure, physical and telematic", both in terms of the priority objectives of the NSP and in the region. This axis in the regional program further defines specific objectives: improving the conditions necessary to foster the permanence of farms in rural areas (through improvements in infrastructure and the sustainable use of water resources, including treated wastewater for irrigation and drinking purposes for business use); increasing the level of workers' professional skills in the agricultural and forestry sector, while improving their

\footnotetext{
7. In the rural regional plan, the strategic matrices aimed to demonstrate perfect coherence between the European, national, and regional strategic guidelines (axes 1, 2, 3, and 4). For additional details, see Regione Puglia, 2008, p. 4889-4892.
} 


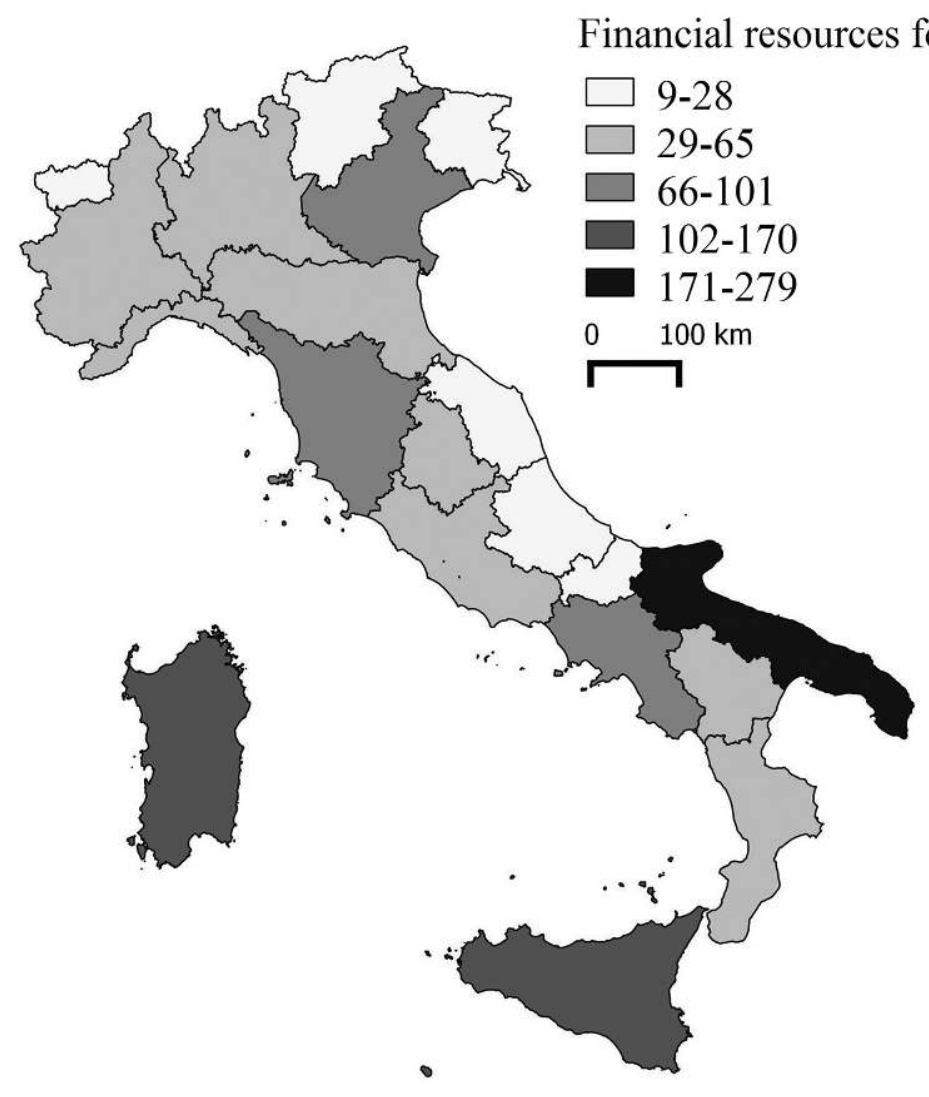

Figure 3: Distribution of financial resources on axis 4 in the Italian regions (Source: Our elaboration on Sotte and Ripanti, 2008, p. 15 and Regione Puglia, 2008)

Répartition des ressources sur l'axe 4 dans les régions italiennes

knowledge, skills, and compliance toward environmental and safety at work prescribed by Community legislation; and promoting generational turnover in agriculture for young people (Regione Puglia, 2008, p. 4889). The region programmatically focuses on improving the level of knowledge, skills, and entrepreneurial skills of the local players, as well as on improving the supply and use of essential services to the population (especially to those who are vulnerable), even in axis 3. In this axis, particular attention is also given to the requalification of villages, to the elements and anthropic landscape of the rural heritage, to specific interventions for the management and preservation of the territory, and to the landscape conservation and enhancement of cultural heritage. However, particularly emblematic is the declination of axis 4 (see Regione Puglia, 2008, p. 4981-4992), where the improvement of governance is reduced to a mere increase in the ability to develop projects for the territories, as well as to the complex mobilization of endogenous potential to the valorization of punctual local resources. In this axis, the highest level of hierarchy, as well as its close alignment to European and national objectives, can be seen. This is confirmed by a lack of specification and declination (as characterized by a lack of clear objectives), which also occurs - with obvious limitations - in all other axes.

With respect to the full-blown need to innovate the production system of Puglia, the proposed solution is to increase direct investment, so as to introduce product innovations and processes aimed at achieving business competitiveness and attractiveness within the territories (especially towards foreign investors). Overall, a specific interpretation of innovation - and, therefore, of spatial development - emerges; this refers to a vision that we could argue is orthodox Fordist in terms of its product innovation, process, technology, and standardized knowledge (when taken out of the territorial context), were it not for the reference to specific local production (as in the case of the mechanization of wine production).

Yet still, in this regard, the analysis of the LAGs' development plans confirms the strong role played by the region in defining objectives and strategies. 
Therefore, it can be said that the model of regional governance is strongly hierarchical and prescriptive; thus, it effectively limits the autonomy of the territories in defining their own vision of development (see also De Rubertis et al., 2015). However, it may be noted that some LAGs, especially those more rooted in the territory (and this is not by chance, according to the relational approach defined above), are affected to a more limited extent. In fact, when the plans deal with the theme of innovation strategies, they make explicit reference to integration and innovation. In fact, considering the territorial context, the plans propose to intervene by the following: building and strengthening networks of actors and sectors for integrated development (such as with the following LAGs: Terra D’Arneo, Terre dei Trulli e di Barsento, Santa Maria di Leuca, Valle d'Itria, Terra d'Otranto, Terre del Primitivo, and Città di Castel del Monte); playing a driving and coordinating role, particularly with the other inter-communal cooperation instruments within the territory (such as the LAGs Terre di Murgia and Colline Joniche); and developing local social capital - in many cases, proposing operational and original solutions. A deeper study of these solutions shows a certain degree of innovation and originality. They range from the simple creation of thematic tables, to actions that extend participation to external entities (LAG Murgia Più), to the establishment of operative agencies for tourism development in the territory (LAG Luoghi del Mito), the creation of platforms and local centers designed to foster innovation - and to project strong and competitive equipment (LAGs Piana del Tavoliere and Ponte Lama), and the creation of complex networks of branch itinerants to bring innovation to farms (LAG Sud Est Barese) ${ }^{8}$ (figure 4). The territories propose or realize these projects (such as the detailed study and stages that integrate the description of the Local Innovation Platform) which, in many cases, represent real innovations within the local context. In many instances, these are pilot projects described in the Local Development Plans, but whose numbers are still limited when compared with those of LAGs in the region. In this case, a more detailed inquiry should verify not only the practical implementation and its status, but also the relationships between the promoters, the procedures, and the effective invol-

8. The projects are as stated and reported by all LAGs in the section titled "Innovation" of the Local Development Plans. vement of local communities, as well as the possible replicability of these projects.

In the second phase, the research focused on a census search and analysis of calls officially published from 2010-2015. The study focused on the role of LAGs, as well as on the quality and objectives of the proposed projects. The calls that were analyzed show a particular concentration of resources; they therefore represent the projects in axis 3 (referred to as quality of life in rural areas and diversification of rural economy), particularly for measures related to the diversification of agricultural activity; this is followed by incentivation of tourist activity, support for business start-ups and development, protection and enhancement of rural heritage, training and information services, and essential services for the economy and rural population (which are particularly in favor of certain categories of people, especially young people and women) (figure 5). The analysis of the projects highlighted a specific productivist-economic orientation of the interventions, even when these were directed toward training and information (the aim of training is to raise levels of knowledge, professional skills, and entrepreneurial capacities). The project quality and the number of calls for measures seem to show that the indications from a programmatic point of view (in the regional rural plan) are disregarded. The implementation of axis 4 (implementing the LEADER approach) is very demonstrative; it consists of the performance of mere services for the concrete initiation of the activities in LAGs (such as management and their acquisition of competences).

This all pays little attention to innovation in terms of increasing knowledge and governance in rural areas. Innovation essentially concerns businesses more than the territories; very few interventions are designed to improve the social, cultural, and institutional contexts in these areas. Innovation has promoted the benefit to businesses and production processes, and it exhibits a strictly economic and technological connotation; it shows little interest in the systemic processes of the social constructs in which it should be grounded. The great dependence on community, national, and (above all) regional strategic orientations, as well as on the marked hierarchical role of control exercised by the region, leaves LAGs no space for autonomy, especially at the operative level. Although the LAGs have bowed 


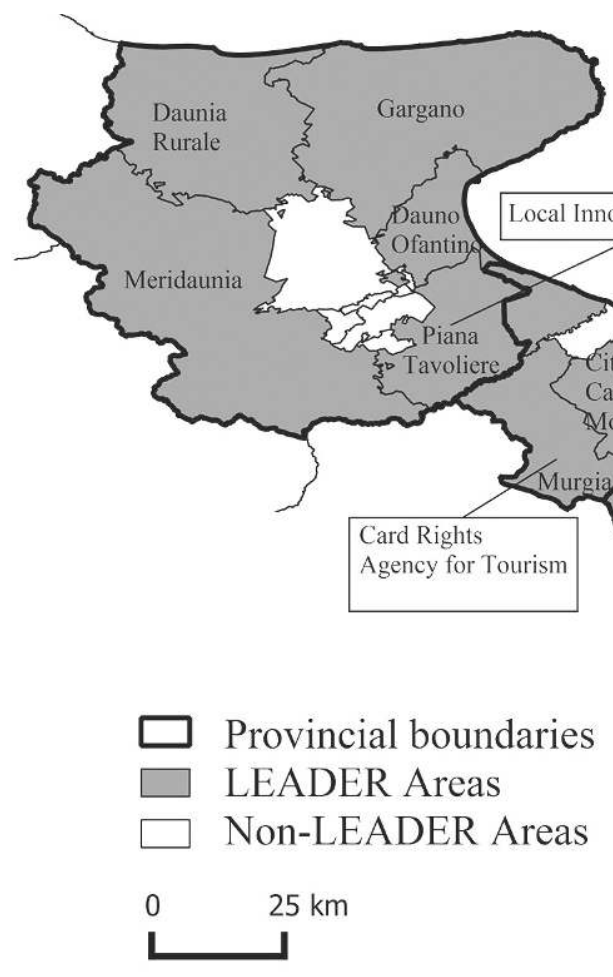

Figure 4: Boundaries of Apulian LAGs in Puglia, as well as some innovative projects Limites des groupes d'action locale dans les Pouilles, et quelques exemples de projets innovants

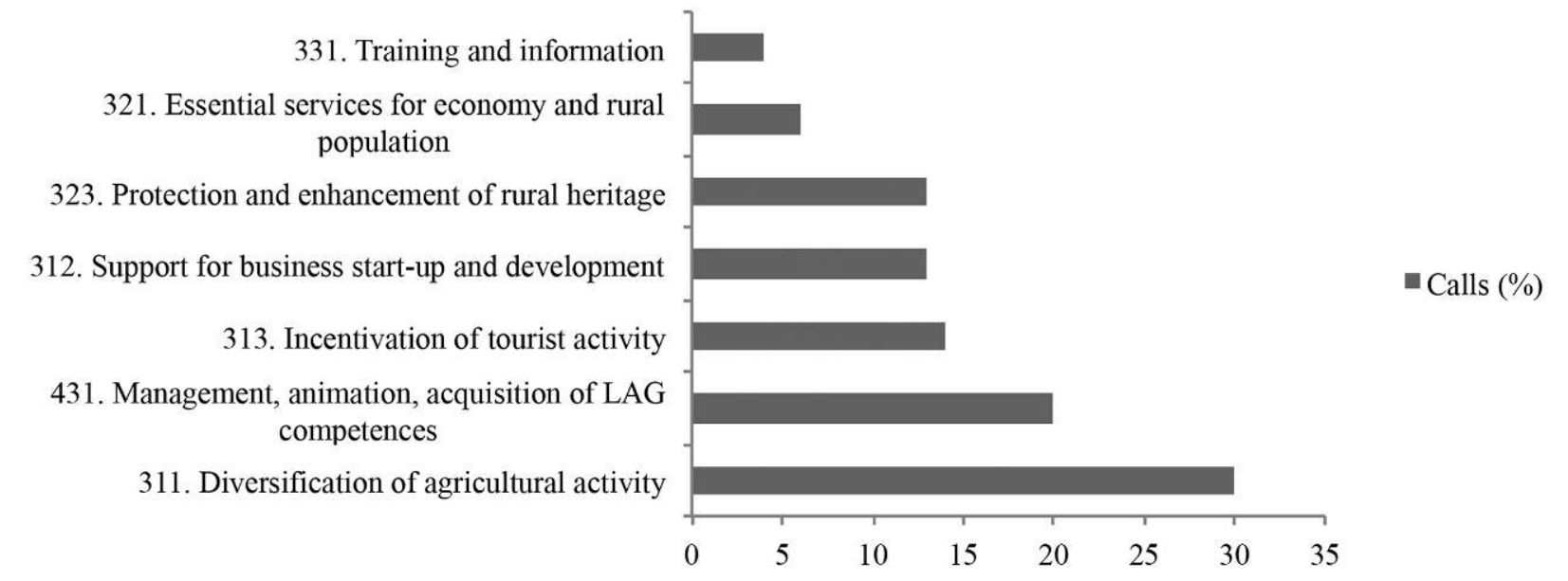

Figure 5: Intervention measures and the corresponding calls for applications of Apulian LAGs. Source: Our elaboration on Rete Rurale Nazionale, 2014

Les mesures d'intervention et les appels publics correspondants aux groupes d'action locale dans les Pouilles

to regional requirements they have, in some cases, shown creativity and profound understanding of the territories in which they operate, proposing original and innovative solutions (which, however, need to be investigated in greater depth).

\section{Conclusions}

As argued in this paper, the role of innovation and knowledge in the development of territories, especially in rural areas, is of particular importance for 
the regions under the Convergence Objective, and specifically for Puglia. As is known, in the European Community innovation is widely regarded as a key factor in the economic growth and competitiveness of a region, but its social and cultural dimensions are often overlooked.

Only in recent years innovation has been conceived in the literature as a co-evolutionary learning process that occurs within social networks. In this sense, the LEADER approach, which has been integrated in the last programming cycle of the CAP, represents an emblematic change; it also serves as the basis for sustainable rural development - especially of the economic, social, and cultural constructs and institutional capacities of the territories (Dargan and Shucksmith, 2008). This approach represents a mode of innovation that has long existed in the public policies geared toward rural development.

The mobilization of neo-endogenous development strategies characterized by valorizing and exploiting local resources - both physical and human - emphasizes the more democratic and participative forms of local government, focusing on the role of social capital (Ray, 2006). It has been attracting more and more interest and is a key driver of the LEADER approach (EC, 2006). The promotion of networks and social capital in the development process can have long-term and positive results. At the same time, however, the networks and social capital can be used by individuals or groups to limit the acquisition of benefits arising from these changes. Rural developments that build upon neo-endogenous strategies can be successful, but only if they also encourage and support the development of social innovations; however, these are often not well analyzed. Innovation, according to its common understanding, focuses on material and product innovation, on the methods of innovation or production processes, as well as on marketing and organizational innovation in the field of economics. As a result, in policy, innovation is still almost exclusively treated and perceived as economic, which focuses on technical efficiency. Case studies on different European countries confirm the very weak impact of the LEADER approach in terms of its effectiveness, which extends above and beyond the limitations associated with the implementation of its strategy and innovation at the local scale (Dax et al., 2016;
Navarro et al., 2016 ; Nemes et al., 2015 ; Chevalier, 2014). In fact, the interpretation of innovation can tell a lot about the strategies and governance model adopted at the local scale. Therefore, the case of Puglia demonstrates that a reductive interpretation of innovation underlies the specific choices and orientations of the strategies and governance model adopted at a local scale.

The analysis carried out of the main planning documents for Puglia, spanning the 2007-2013 period, confirms the marked dependency on national and community orientations, probably with the main aim of guaranteeing that these projects conform to the specific criteria required for them to receive funding. Innovation essentially refers to the productivity and competitiveness of businesses, with interventions directed only toward minimally improving the social, cultural, and institutional contexts. This attitude indicates that the LAGs are aligned to the mainstream rhetoric of rural development, which is based on a merely productivist approach that, in many cases, reveals deeply-rooted conservativeness in program planning and implementation. This interpretation of the term is associated with a highly centralized, traditional, and prescriptive governance model in which participation plays a marginal role, and where local actors (and, therefore, territories) play a passive role. It is thus not surprising that many networks of actors are relatively limited, and that social innovation is not well supported by regional financing. The adopted governance model merely limits the potential for innovation within the territories, as it is strongly constrained by the EU, as well as by national strategies and objectives (see also De Rubertis et al., 2015). As demonstrated above, however, the strong role played by the region affects the innovation strategies of some LAGs of Puglia to a lesser extent, especially those more territorially rooted; these strategies propose to intervene by building and strengthening networks of actors and areas for integrated development, developing local social capital, and implementing operational and original projects. This reflects what was observed at the European scale. According to the annual report published by the Società Geografica Italiana (2012), the EU - unlike other countries (United States, New Zealand, and Australia) - has opted for a multifunctional model that effectively keeps a regime of assistance and control over the sector, 
even though it is currently moving toward a liberal politic. This evolution has not reduced the rather high level of institutionalization that characterizes this sector. Consequently, the rootedness of these institutions ensnares the change process, operating a real filtering of external innovative stimuli and constraining, from an operational point of view, the behavior of political actors and institutions. According to Fløysand and Jakobsen (2010), the recent approach to innovation has been influenced by the development of strong links between research and policy. The innovation was intended to serve as a standardized model for best practices and it was instrumentally used to regulate system failures within national, regional, and even local systems.

In conclusion, it can thus be stated that some new initiatives recognize the importance of social innovation, demonstrating that social sustainability is often a prerequisite for innovation. Furthermore, it also illustrates that the various components of human, social, and educational measures are essential to implement innovations. The LEADER approach seeks to take this direction, but the success of its strategies depends heavily on its ability to recognize the value of territorial diversity and to mobilize public participation, which ultimately focuses on social, economic, and cultural renewal.

Finally, this study highlights the limits at the local scale: on the one hand, there is a high degree of complexity when addressing and implementing European policies and practices, yet the routine behaviors of limited interest groups frequently dictate how innovation is interpreted. Conversely, strict and formal hierarchical control in this region has left little room for interactive learning and innovation among the parties involved; these parties should instead focus on concretely implementing these strategies. In the future, for the 2014-2020 planning cycle, if these limits were to recur, the impact and innovative nature of the LEADER approach may be completely nullified by the consolidation of traditional rhetoric and practices. In this sense, a decisive role must be played by the regional government, whose coordination and control is critical in preventing opportunistic behavior from emerging; moreover, the government can also prevent elites from engaging in lock-in or closing mechanisms during the innovation process. A decisive role must be played by local actors, who should no longer passively participate in decision-making processes, nor should they engage in performing formal adjustments. Rather, they must critically reflect on previous experiences and engage in greater openness to new actors and learning experiences in an attempt to discover new and unvalorized local potentialities by leveraging more appropriate resources. On another note, due to the complexity of innovation, a single global strategy is likely to be inadequate to provide the right stimuli and incentives in different contexts. On a European scale, as suggested by the policy recommendations of KIT (2012, p. 49), a "one-sizefits-all" innovation policy is no longer acceptable. In fact, "the European innovation policies have to move away from a thematically/regionally neutral and generic innovation strategy; they require instead to be based on a thematically/regionally focused innovation policy approach".

In conclusion, although the implementation of the LEADER model has, in some ways, promoted cooperation and interaction between different areas and actors, the logic that serves as the basis for its social and political formation can vary significantly, in many cases, strengthening the power and control of its stakeholders and local elites. In short, despite the fact that social innovation (of the context) appears to be a key factor in rural development and it is seen in social and cultural terms rather than as a technological issue, in many cases, including the Puglia region, it has been interpreted by national and, above all, by local policies almost exclusively in the latter sense. In Puglia, the dominant practice has underrated innovation (in the broadest sense), and consequently it received only lukewarm support during 2007-2013 programming cycle. On the one hand, social, cultural and institutional innovation, have been poorly supported by the regional planning, while on the other, a general difficulty by the LAGs emerged, in which innovation was too complex to implement and usually reduced to banal business or usual techniques. 


\section{Acknowledgements}

The author thanks the anonymous referees for critical and helpful comments.

\section{Bibliography}

Aydalot P., 1985. Economie régionale et urbaine, Paris, Economica, $487 \mathrm{p}$.

Aydalot P., 1986. Présentation, in Groupe de Recherche Européen sur les Milieux Innovateurs (GREMI), Milieux innovateurs en Europe [http://wwwa.unine.ch/irer/Gremi/Gremi 1.pdf].

Boschma R.A, 2005. Proximity and Innovation: A Critical Assestment, Regional Studies, vol. 39 (1), p. 61-74.

Camaioni B., Sotte F., 2009. I Psr in Italia. Stato di avanzamento e realizzazione, in SotTe F. (dir.), La politica di sviluppo rurale 2007-2013. Un primo bilancio per l'Italia, Gruppo 2013, Edizioni Tellus, p. 17-55 [http://www. gruppo2013.it/workingpaper/Documents/La politica di sviluppo rurale 2007-2013.pdf].

Chevalier P., 2014. Action locale et développement rural en Europe: Le modèle européen LEADER 2007-2013, Bruxelles, P.I.E. Peter Lang, 202 p.

Cloutier J., 2003. Qu'est-ce que l'innovation sociale?, Cahier du CRISES, coll. «Études théoriques », nº ET0314 [http:// crises.uqam.ca/upload/files/publications/etudes-theoriques/ CRISES_ET0314.pdf].

Conti S., 2013. Sul divenire delle regioni. Problemi irrisolti e scenari possibili, Mélanges de l'École française de RomeItalie et Méditerranée modernes et contemporaines, 125-2. [http://mefrim.revues.org/1436].

Copus A.K, de Lima F. (dir.), 2015. Territorial Cohesion in Rural Europe. The relational turn in rural development, Routledge, UK, $254 \mathrm{p}$.

Crevoisier O., 2004. The Innovative Milieus Approach: Toward a Territorialized Understanding of the Economy?, Economic Geography, issue 4, vol. 80, p. 367-379.

Dax T., Strahl W., Kirwan J., Maye D., 2016. The Leader programme 2007-2013: Enabling or disabling social innovation and neo-endogenous development? Insights from Austria and Ireland, European Urban and Regional Studies, issue, 1, vol. 23, p. 56-68.

Dargan L., Shucksmith M., 2008. Leader and Innovation, Sociologia Ruralis, issue 3, vol. 48, p. 274-291.

De Rubertis S., Belliggiano A., Labianca M., 2015. Leader Programme in Apulia: rural development and innovation needs, in Vrontis D., Tsoukatos V., Maizza A. (dir.), Innovative Management Perspectives on Confronting Contemporary Challenges, Cambridge Scholars Publishing, UK, p. 101128.

Dwyer J., Ward N., Lowe P., Baldock D., 2007. European Rural Development under the Common Agricultural Policy's "Second Pillar": Institutional Conservatism and Innnovation, Regional Studies, issue 7, vol. 41, p. 873-887.
EC-European Commission, 2009. Creativity and Innovation in EU Rural Development, EU Rural Review, The Magazine from the European Network for Rural Development, $\mathrm{n}^{\circ} 2$. [https://enrd.ec.europa.eu/sites/enrd/files/fms/pdf/B99849C000E8-A7DC-1D6A-775E2ED9F89A.pdf].

EC-European Commission, 2013. Knowledge Transfer and Innovation in Rural Development Policy, EU Rural Review, A Publication from the European Network for Rural Development, $\mathrm{n}^{\circ}$ 16. [https://enrd.ec.europa.eu/sites/enrd/files/fms/ pdf/89E54472-A7ED-41AD-84A6-C392AD7ECE14.pdf].

EC-European Commission, 2006. The Leader approach. A basic guide. [http://ec.europa.eu/agriculture/publi/fact/leader/2006_en.pdf].

EC-European Commission, 2014a. Research and innovation as sources of renewed growth [http://ec.europa.eu/research/ innovation-union/pdf/state-of-the-union/2013/research-andinnovation-as-sources-of-renewed-growth-com-2014-339-final.pdf].

EC-European Commission, 2014b. Taking stock of the Europe 2020 strategy for smart, sustainable and inclusive growth. [http://ec.europa.eu/europe2020/pdfleurope2020stocktaking_en.pdf].

EU-European Union, 2009. Knowledge and Innovation. [http://cor.europa.eu/en/documentation/studies/Documents/ Knowledge_and_Innovation.pdf].

Espon, 2012, EDORA-European Development Opportunities in Rural Areas. [http://www.espon.eu/main/Menu_Projects/ Menu_AppliedResearch/edora.html].

EsPon, 2012, KIT-Knowledge, Innovation, Territory. [http://www. espon.eu/export/sites/default/Documents/Projects/AppliedResearch/KIT/FinalReport/KIT_Final-Report_final.pdf].

EsPON, 2012, SIESTA - Spatial Indicators for a 'Europe 2020 Strategy'. Territorial Analysis Applied Research Annex C Research and Innovation. [http://www.espon.eu/export/sites/ default/Documents/Projects/AppliedResearch/SIESTA/DFR/ SIESTA_DFR_Annex_C.pdf].

Fløysand A., Jakobsen S.E., 2010. The complexity of innovation: A relational turn, Progress in Human Geography, issue 3, vol. 35, p. 328-344.

Fontan J.-M., Klein J.-L., Trenblay D.-G., 2004. Innovation et société, pour élargir l'analyse des effets territoriaux de l'innovation, Géographie, économie, société, issue 2, vol. 6, p. 115-128.

Groupe de Recherche Européen sur les Milieux Innovateurs (GREMI), 1986. Milieux innovateurs en Europe. Milieux innovateurs en Europe [http://wwwa.unine.ch/irer/ Gremi/Gremi 1.pdf].

ineA - Istituto Nazionale di Economia Agraria, Ministero delle Politiche Agricole Alimentari e Forestali, CRA - Consiglio per la Ricerca e la sperimentazione in Agricoltura, 2009. Il fabbisogno di innovazione alla luce delle politiche di interesse per lo sviluppo rurale. [http:// www.reterurale.it/flex/cm/pages/ServeBLOB.php/L/IT/IDPagina/2925].

Jessop B., 1995. The Regulation Approach, Governance, and Post-Fordism: Alternative Perspectives on Economic and 
Political Change?, Economy and Society, issue 3, vol. 24, p. 307-333. [http://eprints.lancs.ac.uk/203/].

Knickel K., Tisenkopfs T., Brunori G., 2009. Innovation processes in agriculture and rural development: the IN-SIGHT project, in Knickel K., Tisenkopfs T., Peter S. (dir.), Innovation processes in agriculture and rural development. Results of a cross-national analysis of the situation in seven countries, research gaps and recommendations [http://www.insightproject.net/files/IN-SIGHT_final_report.pdf].

Leader European Observatory, 1997. Innovation and Rural Development, The Observatory Dossiers n. 2.

Lee J., Árnason A., Nightingale A., Shucksmith M., 2005. Networking: Social Capital and Identities in European Rural Development, Sociologia Ruralis, issue 4, vol. 45, p. 269-283.

Ministero dello Sviluppo Economico - Dipartimento per LE POlitiche di SVILuppo E di Coesione, 2007. Quadro Strategico nazionale per la politica regionale di sviluppo 2007-2013. [http://www.dps.tesoro.it/].

Murdoch J., 2000. Networks - a new paradigm of rural development?, Journal of Rural Studies, issue 2000, vol. 16, p. 407-419.

Navarro F.A., Woods M., Cejudo E., 2016. The LEADER Initiative has been a Victim of Its Own Success. The Decline of the Bottom-Up Approach in Rural Development Programmes. The Cases of Wales and Andalusia, Sociologia Ruralis, 56, p. 270-288.

Nemes G., High C., Augustyn A., 2015. Beyond the New Rural Paradigm. Project state and collective reflexive agency, in Copus A.K, DE Lima F. (dir.), Territorial Cohesion in Rural Europe. The relational turn in rural development, Routledge, UK, p. 212-235.

Neumeier S., 2012. Why do Social Innovations in Rural Development Matter and Should They be Considered More Seriously in Rural Development Research? - Proposal for a Stronger Focus on Social Innovations in Rural Development Research, Sociologia Ruralis, issue 1, vol. 52, p. 48-69.

Prezioso M., 2007. Governance for Territorial Cohesion and Sustainable Development in Europe, in Bencardino F., Prezioso M. (dir.), European Territorial Cohesion and the
Sustainable Development: Convergence and Competitiveness, Milano, F. Angeli, p. 243-279.

Prezioso M., 2008. Cohesion policy: methodology and indicators towards common approach, Romanian Journal of Regional Science, issue 2, vol. 2.

Proost J., Brunori G., Fischler M, Rossi A., Šūmane S., 2009. Knowledge and social capital, in Knickel K., TisenKOPfS T., PETER S. (dir.), Innovation processes in agriculture and rural development. Results of a cross-national analysis of the situation in seven countries, research gaps and recommendations. [http://www.insightproject.net/files/IN-SIGHT_ final_report.pdf].

Ray C., 2006. Neo-endogenous development in the EU, in Cloke P., Marsden T., Mooney P.H. (dir.), Handbook of rural studies, London, Sage, p. 278-291.

Regione Puglia, 2008. Programma di sviluppo rurale 20072013, Bollettino Ufficiale della Regione Puglia, issue 34, 29-2-2008, p. 4728-5659.

Rete Rurale Nazionale, 2014. Leader Bandi Gal Regione Puglia. [http://www.reterurale.it/leader/bandigalpuglia].

Shearmur R., 2011. Innovation, Regions and Proximity: From Neo-Regionalism to Spatial Analysis, Regional Studies, issue 9, vol. 45, p. 1225-1243.

Shucksmith M., 2000. Endogenous development, social capital and social inclusion: perspectives from LEADER in the UK, Sociologia Ruralis, issue 2, vol. 40, p. 208-218.

Società Geografica Italiana, 2012. Rapporto anmuale 2012. I nuovi spazi dell'agricoltura italiana, Rome, Società Geografica Italiana, p. 133.

Sotte F., Ripanti R., 2008. I Psr 2007-2013 delle Regioni italiane. Una lettura quali-quantitativa, Rome, Gruppo 2013 [http://www.gruppo2013.it/working-paper/Documents/WP PSR 20072013 Sotte Ripanti.pdf//www.insightproject.net/ files/IN-SIGHT_final_report.pdf].

Van Hemert P., Masurel E., Nijkamp P., 2011. The role of knowledge sources of SMEs for innovation perception and regional innovation policy, Regional Science Policy and Practice, issue 3, vol. 3, p. 164-179.

Ward N., Brown D.L., 2009. Placing the Rural in Regional Development, Regional Studies, issue 10, vol. 43, p. 1237-1244. 